\title{
ETIKA PELAJAR DALAM PERSPEKTIF IBN JAMA'AH
}

\author{
Ahmad Yusam Thobroni \\ (Dosen FITK IAIN Sunan Ampel)
}

\begin{abstract}
Abstrak
Tulisan ini memaparkan tentang "Etika Pelajar dalam Perspektif Ibn Jama'ah". Konsep pendidikan Ibn Jama'ah merupakan konsep pendidikan yang cenderung memposisikan pelajar sebagai objek dalam pendidikan, sehingga pelajar kurang mendapat kesempatan untuk 'diberdayakan'. Pelajar hanya dipandang sebagai manusia yang menerima dan menyimpan segala pengetahuan yang diperolehnya dengan tanpa diberi kesempatan untuk bersikap aktif, kreatif dan inovatif. Oleh karena itu konsep ini kurang relevan jika diterapkan pada konsep pendidikan sekarang yang membutuhkan paradigma baru dengan memposisikan pelajar sebagai subjek dalam kegiatan belajar-mengajar. Meski demikian, tidak semua pemikiran Ibn Jamaa'ah yang berkaitan dengan konsep pendidikan tidak sesuai dengan kondisi kekinian, karena sebagian konsep pendidikan yang ditawarkan masih relevan dan cocok jika diterapkan pada pelaksanaan pendidikan saat ini (misalnya, pemikirannya berupa pelajar harus selalu menghiasi dirinya dengan akhlak mulia ketika menuntut ilmu). Oleh karena etika merupakan media selfcontrol (pengawasan melekat) terhadap diri pelajar yang dapat menghindarkannya dari hal-hal negatif, dimana hal ini berguna untuk mendukung kesuksesannya dalam belajar.
\end{abstract}

Kata Kunci: Ibn Jama'ah, Guru dan Pelajar 


\section{A. Pendahuluan}

Pendidikan merupakan tuntunan pertumbuhan manusia sejak lahir hingga tercapai kedewasaan jasmani dan ruhani, dalam interaksi dengan alam dan lingkungan masyarakatnya. Pendidikan merupakan proses yang terus menerus, tidak berhenti. Di dalam proses pendidikan ini, keluhuran martabat manusia sangat diutamakan karena ia mrenjadi "subjek" dari pendidikan tersebut. Karena manusia menjadi subjek dalam pendidikan maka ia dituntut oleh suatu tanggung jawab agar tercapai suatu hasil pendidikan yang baik. ${ }^{1}$ Oleh karena manusia sebagai pelajar dalam kegiatan pendidikan dibebani suatu tanggung jawab yang berat demi tercapainya tujuan pendidikan, maka manusia (pelajar) harus memiliki etika-etika yang baik yang dapat menunjang keberhasilan belajarnya.

Pendidikan adalah aktifitas yang sengaja dilakukan untuk mngembangkan individu secara penuh. Karena itu, norma, etika dan nilai-nilai keutamaan menjadi penting dalam semua perencanaan pendidikan. ${ }^{2}$ Dalam kegiatan formal pendidikan, pelajar merupakan unsur yang sangat menentukan, di samping unsur guru. Karena keduanya merupakan aset hidup yang mampu mengolah dan melaksanakan unsurunsur lainnya yang merupakan aset mati. Di samping itu pelajar adalah manusia yang sedang berada dalam proses perkembangan dan pertumbuhan yang memerlukan pendidikan untuk mengaktualkan potensinya. ${ }^{3}$ Untuk memenuhi kebutuhan manusia akan pendidikan, maka dilaksanakanlah kegiatan belajar-mengajar yang di dalamnya ada kegiatan penting yaitu belajar yang berarti suatu proses dari seorang individu yang berupaya mencapai tujuan, yaitu suatu bentuk perubahan tingkah laku yang relatif menetap. ${ }^{4}$

\footnotetext{
${ }^{1}$ Suwito, Pendidikan yang Memberdayakan, dalam pidato pengukuhan Beliau sebagai guru besar sejarah pemikiran dan pendidikan Islam,UIN Syarif Hidayatullah Jakarta, 2002, 23.

${ }^{2}$ Ali Ashraf, Horizon Baru Pendidikan Islam (Jakarta: Pustaka Firdaus, 1993), 1.

${ }^{3}$ M. Arifin, Hubungan Timbal Balik Pendidikan Agama; di Lingkungan Sekolah dan Keluarga (Jakarta: Bulan Bintang, 1976), 110.

${ }^{4}$ Mulyono Abdurrahman,Pendidikan Bagi Anak Berkesulitan Belajar(Jakarta: PT. Rineka Cipta, 1999), 28.
} 
Pelajar adalah manusia yang mampu dididik dan membutuhkan pendidikan dalam rangka mengaktualkan potensi yang ada pada dirinya serta untuk mendapatkan ilmu pengetahuan untuk memenuhi kebutuhan hidup dan sebagai bekal beribadah kepada Allah. Oleh karena ilmu merupakan sesuatu yang sangat berharga, maka seseorang yang menuntut ilmu sepantasnya membekali dirinya dengan akhlak yang mulia—sebagai upaya persiapan diri- demi keberhasilannya. ${ }^{5}$

Tulisan ini berupaya memahami etika pelajar dalam pemikiran Ibn Jama'ah berdasarkan pemahaman penulis terhadap karya Beliau yang berjudul Tadzkirah al-Sâmi' wa al-Mutakallim fì Adab al-'lim wa alMuta'allim dalam bab III, tentang etika pelajar. Dalam pada itu, Ibn Jama'ah menempatkan orang-orang yang berilmu pada posisi tinggi melebihi orang yang ahli ibadah, karena orang-orang yang berilmu adalah pewaris para Nabi. ${ }^{6}$ Ibn Jama'ah mendasarkan pemikiran ini pada Hadis Nabi:

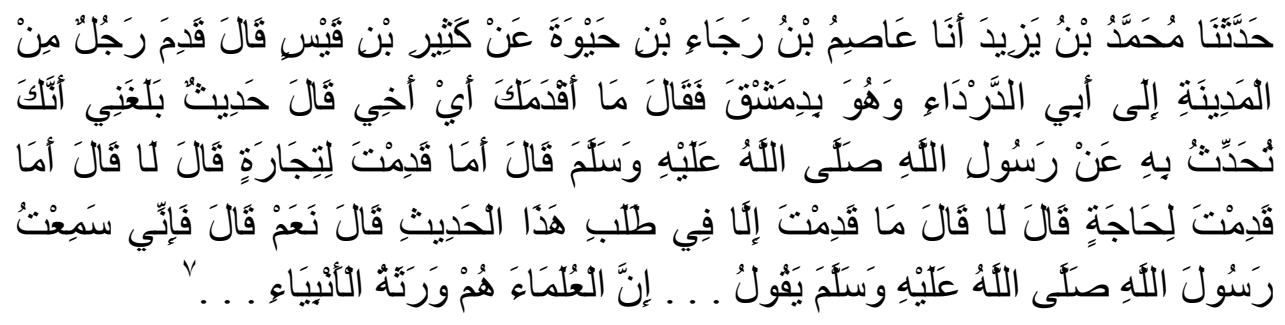

\section{B. Riwayat Hidup Ibn Jama'ah}

Nama lengkap Ibn Jama'ah adalah Badruddin Muhammad Ibn Ibrahim Ibn Sa'adullah Ibn Jama'ah Ibn Hazim Ibn Shakhr Ibn Abdullah al-Kinaniy al-Hamwa al-Syafi' 'iy. ${ }^{8}$ Beliau dilahirkan pada malam Sabtu, 4 Rabi'ul Akhir 639 H. bertepatan dengan bulan Oktober 1241 M. di

\footnotetext{
${ }^{5}$ Oleh karena ilmu itu cahaya, maka pelajar sepatutnya mengkondisikan diri dan hatinya dalam suasana kesucian, guna menangkap cahaya (ilmu) tersebut.

6 Ibn Jama'ah al-Kinaniy, Tazkirah al-Sami' wa al-Mutakallim fi Adab al- 'lim wa al-Muta'allim (Beirut:Dar al-Kutub al-Ilmiyah,tth.), 5-6.

7 Ahmad bin Hanbal, Musnad Ahmad bin Hanbal, no. hadis 21152, CD ROM Maus-' ah al-Hadis al-Syarif (Kuwait: Sakhr al-'Alamiah Software, 1996).

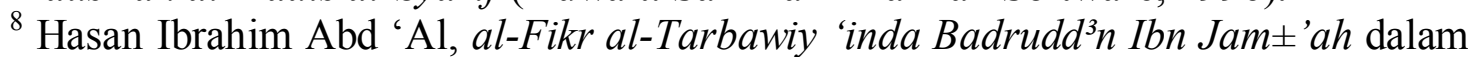
Min A'lām li al-Tarbiyah al-Islamiyyah, jilid 3 (tt.: Maktabah al-Tarbiyah al-'Arabi li dauli al-Khalij), 275.
} 
Hamah, ${ }^{9}$ dan wafat pada malam Senin 21 Jumadil Ula 733H/1333 M. dalam usia 94 tahun, satu bulan dan beberapa hari. Beliau setelah dishalatkan di masjid Jami' al-Nashiriy Mesir kemudian dimakamkan di Qirafah. ${ }^{10}$

Ibn Jama'ah termasuk salah satu dari beberapa pemikir Muslim termasyhur di Mesir pada masa itu. Ibn Jama'ah hidup pada masa akhir pemerintahan dinasti Ayyubiyah dan pada masa dinasti Mamalik Bahriyah. ${ }^{11}$ Dua dinasti ini merupakan dinasti yang berkuasa di Mesir. Bila dilihat perjalanan sejarah, Mesir adalah negara yang selamat dari serangan Mongol maupun Timur Lenk. Oleh karena negeri ini terhindar dari kehancuran, maka perkembangan peradabannya masih terus berlangsung, termasuk dalam dunia ilmu pengetahuan banyak berkembang dan melahirkan ilmuwan-ilmuwan terkenal pada masa itu. Tercatat nama-nama besar seperti; al-Razi, Ibn Taimiyah, ibn Khaldun, al-Sayuthi, al-'Asqalani, dan tokoh-tokoh lainnya. ${ }^{12}$ Dan patut pula diketahui bahwa pada masa ini metode berpikir "tradisional" sudah tertanam kuat sejak berkembangnya aliran teologi Asy'ariyah, sedangkan filsafat mendapat kecaman sejak pemikiran al-Ghazali mewarnai pemikiran mayoritas umat Islam. Hal yang penting lagi adalah karena Baghdad dengan fasilitas-fasilitas keilmuannya yang sebelumnya banyak memberi inspirasi ke pusat-pusat peradaban Islam telah hancur. ${ }^{13}$

Ibn Jama'ah hidup di negeri yang memiliki kondisi sosial dan politik yang cukup baik dan stabil serta didukung penguasa yang sangat memperhatikan perkembangan ilmu pengetahuan. Dukungan tersebut diwujudkan dengan pendirian madrasah-madrasah di berbagai tempat yang nantinya menjadi pusat kegiatan belajar-mengajar ulama terkemuka pada masa itu dengan mengajarkan berbagai disiplin ilmu. Alasan lainnya

9 Abd al-Jawad Khalaf, al-Qādli Badruddin Ibn Jamā'ah Hayātuhu Wa Atsaruhu, (Pakistan: Jami'ah al-Dirasah al-Islamiyyah,1988), h.32.

${ }^{10}$ Abd al-Jawad Khalaf, al-Qādli Badruddin Ibn Jamā'ah, 48.

11 Abd al-Jawad Khalaf, al-Qādli Badruddin Ibn Jamā'ah, 94. Mamalik Bahriyah adalah dinasti Mamalik periode I, yang dimulai sejak masa pemerintahan Aybak yaitu sejak berdirinya dinasti ini (1250M.) dan brakhir pada pemerintahan Hajji II (1389M.). Lihat Badri Yatim, Sejarah Peradaban Islam (Jakarta: Raja Grafindo Persada, 1995), 126.

12 Abd al-Jawad Khalaf, al-Qādli Badruddin Ibn Jamā'ah, 127-128.

${ }^{13}$ Abd al-Jawad Khalaf, al-Qādli Badruddin Ibn Jamā'ah, 124. 
adalah karena Ibn Jama'ah dibesarkan dalam keluarga yang sangat mencintai ilmu, faqih, dan zuhud, maka beliau tumbuh dan besar menjadi tokoh dan ilmuwan yang sangat berpengaruh pada masa itu.

Ibn Jama'ah memperoleh pendidikan awal dari ayahnya sendiri, Ibrahim Sa'dullah, yang dikenal sebagai ulama besar, ahli fiqh dan juga seorang sufi. Selain itu ibn Jama'ah juga memperoleh pendidikan dari sejumlah ulama terkenal. Ibn Jama'ah mulai belajar Hadis pada tahun $650 \mathrm{H}$. dari gurunya yang bernama Ibn 'Izzun dan guru-guru lainnya di Hamwa. Kemudian beliau belajar ke Damaskus untuk belajar ilmu-ilmu lainnya kepada beberapa ulama di antaranya Ibn Abi al-Yasar, Ibn Abdillah, Ibn Azraq, al-Najib, Ibn 'Ilaq, al-Mu'in al-Dimasqi, dan lainlain. Beliau juga menuntut ilmu ke Mesir, dan sebagian besar ilmunya dipelajari dari Taqiyyuddin Ibn Ruzain yang terkenal sebagai Qadli.

Selanjutnya beliau juga belajar Nahwu kepada Jamaluddin Ibn Malik, al-Rasyid, al-'Athar, Ibn Abi Umar, al-Taj al-Qasthalaniy, alMajid Ibn al-Daqiq, al-'Id, al-Bushiriy, Ibn abi Salamah, Makiy ibn 'Ilan, ismail al-'Iraqi, dan masih banyak lagi guru-guru lainnya. ${ }^{14} \mathrm{Ibn}$ Jama'ah terkenal sebagai hakim yang adil, pendidik, khatib, dan juga sebagai mufti. Beliau juga mempunyai banyak karya tulis dalam bidang Tafsir, Hadis, Fiqh, ilmu kalam, Nahwu, Adab, dan bidang pendidikan, serta bidang-bidang lainnya.

Adapun nama-nama kitab karya tulis beliau tersebut antara lain: al-Tibyan Fi Mubhamat al-Quran, Ghurur al-Tibyan Fi Man lan Yusamma Fi al-Quran, Kasyf al-Ma'aniy an Mutasyabih Min alMatsaniy, al-Fawaid al-Laihah Min Surah al-Fathihah, al-Munhil alRawi fi Mukhtashar 'Ulum al-Hadis al-Nabawiy, al-Masalik Fi Ilm alManasik, al-Tha'ah Fi Fadlilah Sholatul Jama'ah, al-Mukhtashar alKabir Fi al-Sirah, Tadzkirah al-Sami' Wa al-Mutakallim Fi Adabi alAlim Wa al-Muta'allim, dan masih banyak lagi karya tulis beliau lainnya. ${ }^{15}$ Di samping itu Ibn Jama'ah juga disibukkan dengan kegiatan mengajar di beberapa madrasah, dintaranya mengajar di madrasah Qimriyyah, Kamiliyyah, al-Nashiriyyah, Jami’ Ibn Thulun, al-Adiliyyah,

${ }^{14}$ Ibrahim Hasan Ibn Abd 'Al, al-Fikr al-Tarbawiy, 275-276.

${ }^{15}$ Abd al-Jawad Khalaf, al-Qādli Badruddin Ibn Jamā'ah, 243-273. 
al-Shalihiyyah, al-Zawiyah al-Mansubah Li-al-Syafi'i, dan madrasahmadrasah lainnya. ${ }^{16}$

Adapun kitab Tadzkirah al-Sami' Wa al-Mutakallim Fi Adabi alAlim Wa al-Muta'allim adalah salah satu karya tulis Ibn Jama'ah yang membahas tentang keutamaan ilmu dan orang-orang yang memilikinya, etika orang yang belajar dan mengajarkan ilmu, serta hal-hal lain yang berkaitan dengannya. ${ }^{17}$

\section{Etika Pelajar dalam Pemikiran Ibn Jama'ah}

Menurut Ibn Jama'ah pelajar adalah orang yang belajar dalam kegiatan belajar mengajar. ${ }^{18}$ Ibn Jama' ah dalam pemikiran pendidikannya tampaknya sangat mengutamakan akhlak /etika yang harus dimiliki oleh para pelaksana pendidikan. Menurut hemat penulis, hal ini cukup wajar jika dikaitkan dengan kondisi sosial masyarakat pada waktu itu secara umum, yakni kondisi masyarakat di luar Mesir yang sedang mengalami kemunduran dan kemerosotan moral seiring dengan mundur dan hancurnya pusat-pusat peradaban Islam, maka upaya pembinaan dan penataan kembali moral para pelajar sebagai generasi yang sangat dibutuhkan di masa berikutnya adalah menjadi sangat penting. Pemikiran Ibn Jama'ah tentang pelajar sangat terkait dengan pemikirannya tentang ulama. Menurutnya pelajar yang baik adalah mereka yang memiliki karakter sebagaimana ulama. ${ }^{19}$

Pelajar menurut Ibn Jama'ah harus memiliki tiga etika sebagai berikut:

1. Etika Pelajar terhadap Dirinya ${ }^{20}$

Menurut Ibn Jama'ah pelajar sebagimana seorang guru, haruslah memenuhi syarat-syarat yang penting yang terkait dengan dirinya, motivasi, keinginan, dan kehendaknya. Syarat-syarat ini dikhususkan bagi para pelajar yang menghendaki kedudukan tinggi

\footnotetext{
${ }^{16}$ Ibrahim Hasan Ibn Abd 'Al, al-Fikr al-Tarbawiy.

${ }^{17}$ Ibn Jama'ah al-Kinaniy, Tazkirah al-Sami' wa al-Mutakallim, 4.

${ }^{18}$ Abd. al-Amir Syams al-Din, al-Mazhab al-Tarbawiy 'Inda Ibn Jama'ah (tt.: Dar Iqra', tth.), 27.

19 Abd. al-Amir Syams al-Din, al-Mazhab al-Tarbawiy 'Inda Ibn Jama'ah, 27.

${ }^{20}$ Menurut ibn Jama'ah ada 10 macam 
yang berupa keutamaan dan kemuliaan yang dijanjikan Allah bagi orang-orang yang berilmu.

Oleh karena itu maka pelajar harus:

a. Mensucikan hatinya dari sifat-sifat tercela, misalnya; sifat dengki, hasad, dan "penyakit-penyakit hati lainnya. Hal ini sangat penting bagi pelajar, karena hati yang tidak bersih atau suci tidak akan mampu menerima dan menghafalkan ilmu. Karena menuntut ilmu menurut sebagian ulama' adalah sebagai ibadah hati, maka Ibn Jama'ah berpendapat bahwa sebagaimana shalat yang merupakan ibadah dhahir tidak sah kecuali bila dikerjakan dalam keadaan suci, maka begitu juga dengan menuntut ilmu juga harus ditempuh dengan hati yang suci dari segala kotoran (penyakit-penyakit hati), dan apabila hati itu bersih maka ia akan memperoleh keutamaan atau memperoleh fadlilah dari ilmu itu sendiri. ${ }^{21}$

b. Niat yang baik dan ikhlas dalam menuntut ilmu. Karena niat adalah syarat pokok dalam setiap amal kebaikan, maka menurut ibn Jama'ah seorang pelajar harus memulai belajarnya dengan niat yang baik, yaitu dengan niat menuntut ilmu karena Allah SWT., mengamalkannya, menegakkan syariat, menyinari hatinya, menghiasi batinya, mendekatnya diri kepada Allah serta mengharapkan keridhaan Allah. ${ }^{22}$ Sejalan dengan pendapat Ibn Jama'ah ini Prof. Dr. Suwito, MA.,mengatakan bahwa karena ilmu termasuk sesuatu yang immateri maka harus disertai dengan niat yang benar agar tujuan dari menuntut ilmu itu dapat tercapai. ${ }^{23}$ Apabila dalam menuntut ilmu tidak disertai dengan niat sebagaimana disebutkan diatas serta tidak dibarengi dengan semangat yang tinggi, maka pelajar tersebut akan mengalami kegagalan dan kehilangan akan segala tujuan yang dicitacitakannya.

c. Segera menuntut ilmu sejak usia muda dan sampai akhir hayatnya. Ibn Jama'ah menganjurkan pelajar agar segera menempuh ilmu

\footnotetext{
${ }^{21}$ Abd. al-Amir Syams al-Din, al-Mazhab al-Tarbawiy 'Inda Ibn Jama'ah. 67.

${ }^{22}$ Abd. al-Amir Syams al-Din, al-Mazhab al-Tarbawiy 'Inda Ibn Jama'ah. 68.

${ }^{23}$ Mengutip dari materi perkuliahan Beliau Pada hari Kamis, 20 Juni 2002. dalam matakuliah Sejarah dan Pemikiran Pendidikan. Program pasca sarjana (S2) UIN Syarif Hidayatullah Jakarta.
} 
segera pada waktu usia muda. Pada masa ini ia harus segera mempersiapkan dan melaksanakan belajarnya, karena menunda dan memperlambat akan berbahaya bagi pelajar, maka ia wajib mempergunakan waktu muda itu dengan baik dengan meninggalkan kemalasan. Karena waktu akan terus berjalan dan setiap waktu yang telah dilewatkan dalam hidupnya tidak akan pernah kembali lagi. ${ }^{24}$ Pendapat ini cukup dapat dikaitkan dengan teori yang mengatakan bahwa dalam belahan otak kiri dan otak kanan yang dimiliki manusia itu terdapat ratusan miliar sel otak yang disebut neuron, yang mencakup beberapa triliun jenis informasi dalam hidup manusia, tetapi menurut suatu penelitian sel sebanyak itu yang terpakai hanya sekitar lima persen saja, itupun hanya dapat tercapai jika sel-sel otak tersebut dikembangkan (melalui pendidikan) pada saat manusia itu berusia belasan tahun (pubertas), dan jika pengembangannya tidak dilakukan secara terus menerus maka sel-sel tersebut akan mati. ${ }^{25}$ Untuk itulah maka seseorang sangat dianjurkan untuk segera menuntut ilmu, terutama ketika masih berusia muda.

d. Menghindarkan diri dari kesibukan dunia dan merasa cukup dengan apa yang ada. Ibn Jama'ah berpesan agar seorang pelajar mau hidup "sengsara", merasa puas, rela dengan harta yang sedikit, dan sabar terhadap kesulitan hidup, serta menghindari hal-hal yang dapat mengganggu pikirannya dalam menuntut ilmu. ${ }^{26}$ Imam alSyafi'i berpendapat bahwa seseorang tidak akan memperoleh ilmu dengan limpahan harta sehingga dia berbahagia, akan tetapi orang yang menuntut ilmu hendaklah ia mengerahkan jiwa dan bersedia hidup kekurangan serta mendekati para Ulama karena itu lebih membahagiakan. Karena menuntut ilmu tidak akan berjalan lancar kecuali bagi orang yang pailit, dan bukan bagi orang yang serba

\footnotetext{
${ }^{24}$ Ibn Jama'ah al-kinaniy, Tazkirah al-Sami' wa al-Mutakallim, 70.

${ }^{25}$ Menyitir pendapat DR. Mulyono Abdurrahman dalam perkuliahan Psikologi Pendidikan, pada hari Sabtu,6 April 2002. di Pasca sarjana (S2) UIN Syarif Hidayatullah Jakarta. Lihat pula , Intisari -kumpulan artikel Psikologi anak 2(Jakarta:PT. Intisari Mediatama,1999), 21.

${ }^{26}$ Ibn Jama'ah, Tazkirah al-Sami' wa al-Mutakallim, 71-72.

Jurnal Pendidikan Agama Islam

Volume 02 Nomor 02 November 2013

Hal $310-318$
} 
berkecukupan karena ia akan disibukkan untuk mengurusi harta dan melupakan menuntut ilmu. ${ }^{27}$

e. Mengatur waktunya untuk belajar dan mengajar. Pelajar hendaknya membagi waktu -siang dan malam- sepanjang usianya untuk menuntut dan menyebarkan ilmu. Di samping itu pelajar hendaknya menghindari tempat-tempat yang dapat menggangu konsentrasinya dalam belajar, misalnya; di dekat taman, di dekat sungai, di tengah jalan, di dekat kebisingan, dan tempat-tempat lain yang dapat mengganggu kebebasan hati dalam memahami dan menerima suatu ilmu. Ibn Jama'ah menganjurkan pelajar untuk disiplin dalam menggunakan waktu yang ada. Beliau menganjurkan pada pelajar agar menggunakan waktu sahur untuk menghafal, waktu pagi untuk berdiskusi, siang hari untuk menulis, dan waktu malam untuk muthala'ah dan mudzakarah.. ${ }^{28}$

f. Sedikit makan atau makan sekedar hanya untuk menjaga kesehatan bukan untuk berfoya-foya. ${ }^{29}$ Ibn Jama'ah berpendapat seorang pelajar hendaknya melakukan sesuatu yang dapat membantunya berhasil dalam belajar. Di antaranya dengan makan secukupnya, dan tidak memakan makanan yang dapat membahayakan badan karena hal itu dapat menjadi penghalang baginya meraih sukses dalam belajar. Karena dengan banyak makan dapat menyebabkan pelajar menjadi mengantuk dan malas, sehingga kemampuannya dalam menghafal dan mengingat pelajaraannya menjadi berkurang. ${ }^{30}$

g. Pelajar hendaknya memiliki sifat Wara'. Pelajar hendaknya makan, minum, berpakaian serta bertempat tinggal dengan selalu berhti-

\footnotetext{
${ }^{27}$ Ibn Jama'ah, Tazkirah al-Sami' wa al-Mutakallim, 71-72.

${ }^{28}$ Ibn Jama'ah, Tazkirah al-Sami' wa al-Mutakallim, 72-73.

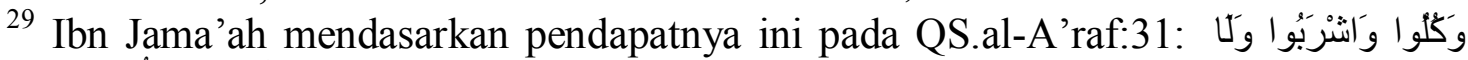

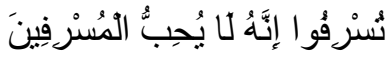

"makan dan minumlah, dan janganlah berlebih-lebihan. Sesungguhnya Allah tidak menyukai orang-orang yang berlebih-lebihan."

Departemen Agama RI, al-Quran dan Terjemahnya (Jakarta: PT.Bumi Restu, 1976), 225.

${ }^{30}$ Ibn Jama'ah, Tazkirah al-Sami' wa al-Mutakallim, 74.
} 
hati dalam menentukan halal dan haramnya, karena sifat ini sangat menunjang keberhasilan belajarnya. ${ }^{31}$

h. Pelajar hendaknya meninggalkan makanan yang menyebabkan ia mudah lupa dan susah dalam memahami dan menghafal pelajarannya.

i. Tidur dan istirahat secukupnya untuk menjaga kesehatan. Ibn Jama'ah juga mengingatkan kepada pelajar untuk memberikan hak pada badannya untuk istirahat. Beliau menganjurkan pelajar untuk menggunakan sepertiga waktu (delapan Jam) dalam sehari untuk tidur dan istirahat. ${ }^{32}$ Teori ini menurut hemat penulis masih tetap sesuai jika diterapkan pada masa sekarang, walaupun tidak harus tepat selama delapan jam tetapi disesuaikan dengan kondisi pelajar itu sendiri.

j. Mencari teman yang shaleh dan tidak bergaul dengan lawan jenis. Teman yang baik (shaleh) akan membantu pelajar itu untuk memperoleh keutamaan dan akan terbawa pada keshalehannya. Di samping itu bila mencari teman, pilihlah teman yang cerdas, yang mempunyai sifat-sifat baik dan sedikit sifat buruknya. ${ }^{33}$ Dari sini dapat dikatakan bahwa Ibn Jama'ah sangat memperhatikan terhadap lingkungan bagi seorang pelajar. Menurutnya lingkungan yang baik adalah lingkungan yang di dalamnya mengandung pergaulan yang menjunjung tinggi nilai-nilai etis. Pergaulan yang ada bukanlah pergaulan yang bebas. Hal ini terlihat pada pendapat beliau bahwa pelajar tidak boleh bergaul dengan lawan jenisnya. Sebab hal itu akan menjadikankan terbuangnya waktu dan menyianyiakan materi. Dan orang yang dapat dijadikan teman pergaulan adalah orang-orang yang menjunjung tinggi nilai-nilai akhlak dan ajaran agama. ${ }^{34}$ Mengenai etika yang terakhir ini tampaknya juga tidak harus diterapkan secara buta, karena bergaul dengan lawan jenis bisa dibenarkan jika pergaulan itu masih berkaitan dengan pengembangan ilmu dan tetap berpegang pada norma-norma agama.

${ }^{31}$ Ibn Jama'ah, Tazkirah al-Sami' wa al-Mutakallim, 75.

${ }^{32}$ Ibn Jama'ah, Tazkirah al-Sami' wa al-Mutakallim, 77-78.

${ }^{33}$ Ibn Jama'ah, Tazkirah al-Sami' wa al-Mutakallim, 84.

${ }^{34}$ Abd. al-Amir Syams al-Din, al-Mazhab al-Tarbawiy 'Inda Ibn Jama'ah, 27. 
2. Etika Pelajar terhadap Gurunya ${ }^{35}$

Oleh karena guru adalah orang yang mempunyai ilmu, maka beliau berhak mendapatkan kemuliaan dan keutamaan sebagaimana orang-orang alim atau ulama karena mereka adalah pewaris para Nabi. Maka Ibn Jama'ah memberikan nasihat-nasihat penting bagi pelajar. Beliau berpendapat bahwa seorang pelajar harus selalu taat dan tawadldlu' kepada gurunya dalam segala urusan. Beliau mengibaratkan ketaatan tersebut dengan "orang sakit dengan dokter yang pandai". Ini adalah salah satu cara memuliakan guru sebgaimana beliau nasihatkan. Di samping itu pelajar haruslah mengetahui hak-hak guru, mendoakan, menghormati dan mensyukurinya. ${ }^{36}$ Maka dari itu ibn Jama'ah juga mengharuskan pelajar untuk memilih seorang guru yang memiliki akhlak yang baik, mampu mengajar dengan baik, dan bertaqwa kepada Allah SWT.

Satu hal yang perlu penulis garis bawahi bahwa Ibn Jama'ah sangat menganjurkan pelajar untuk selalu taat pada guru, walaupun guru itu salah, dan pelajar juga dianjurkan untuk tetap sabar walaupun dimarahi oleh guru. Beliau menganggap kesalahan seorang guru itu masih dianggap baik daripada kebenaran seorang pelajar. Padahal menurut penulis tidaklah harus demikian, karena seseorang harus selalu menegakkan kebenaran terhadap siapapun yang melakukan kesalahan tersebut, meskipun ia adalah guru. Karena Ibn Jama'ah dibesarkan dalam keluarga yang sufi, maka keadaan lingkungan yang demikian menurut penulis turut mempengaruhi pemikirannya tentang etika pelajar terhadap gurunya. Begitu juga dalam masalah ini, Beliau melihat dari perspektif tasawuf yang menempatkan pelajar sebagaimana murid kajian tasawuf di hadapan gurunya.

Pandangan Ibn Jama'ah di atas, untuk masa sekarang tentunya harus dikaji ulang. Saat ini, pelajar harus dibawa pada kreativitas dan semangat dalam belajar. Apabila dikaitkan dengan pendapatnya Paulo Freire, maka pendidikan yang ditawarkan oleh ibn Jama'ah termasuk

${ }^{35}$ Mengenai etika pelajar terhadap guru selengkapnya baca Ibn Jama'ah, Tazkirah al-Sami' wa al-Mutakallim, 85-112.

${ }^{36}$ Secara khusus Ibn Jama'ah membagi bentuk -bentuk ketaatan tersebut menjadi 13 macam. Lihat Ibn Jama'ah, Tazkirah al-Sami'wa al-Mutakallim, 85-110. 
dalam pendidikan yang bergaya bank, dimana ruang yang disediakan bagi para pelajar hanya terbatas pada menerima, mencatat dan menyimpan. ${ }^{37}$ Sementara pendidikan yang dibutuhkan saat ini adalah pendidikan yang membebaskan, pendidikan yang mendorong pada guru dan murid untuk sama-sama menjadi subjek dari proses pendidikan dengan menghilangkan sikap otoriter dan intelektualisme yang mengasingkan. ${ }^{38}$

Menurut Prof. Suwito, dalam pidato pngukuhan guru besarnya, Nabi Muhammad Saw juga memberdayakan para sahabat dan bahkan musuhnya. Nabi Muhammad memperlakukan para sahabatnya sebagai mitra sejajar, egaliter dan berada dalam posisi dan relasi yang demokratis. Sikap nabi yang demikratis ini sebagaimana terlihat dalam dialog nabi dan Mu'ad bin Jabal setelah diangkat sebagai gubernur yaman. ${ }^{39}$ Namun terlepas dari masalah tersebut di atas, di satu sisi Ibn Jama'ah juga memberi kebebasan kepada pelajar untuk memilih guru yang sesuai dengan ilmu yang dikehendakinya, dan memilih guru yang mempunyi akhlak yang luhur, memiliki jiwa kepemimpinan serta bertaqwa kepada Allah. ${ }^{40}$

3. Etika Pelajar terhadap Pelajaran, Halaqah, dan Teman Belajarnya ${ }^{41}$

Pelajar juga dituntut untuk menghormati pelajarannya agar mendapatkan ilmu yang bermanfaat. Adapun etika yang harus dilakukan oleh pelajar terhadap pelajarannya adalah:

a. Pelajaran yang harus dikaji terlebih dahulu adalah al-Quran alKarim dan Hadis serta ilmu-ilmu yang berkaitan dengannya. Kemudian barulah dilanjutkan dengan ushul, nahwu, dan sharaf, karena ilmu-ilmu tersebut merupakan bidang kajian yang penting. ${ }^{42}$

37 Paulo Freire, Pedagogy Of The Oppressed, diterjemahkan oleh Tim Redaksi LP3ES dengan judul Pendidikan Kaum Tertindas (Jakarta: LP3ES, 2000), h. 50.

${ }^{38}$ Paulo Freire, Pedagogy Of The Oppressed,. 70.

${ }^{39}$ Suwito, Pendidikan Yang Memberdayakan, 18-19.

${ }^{40}$ Ibn Jama'ah, Tazkirah al-Sami' wa al-Mutakallim, 85.

${ }^{41}$ Menurut Ibn Jama'ah ada 13 macam.

42 Ibn Jama'ah, Tazkirah al-Sami' wa al-Mutakallim, 112-113. Pendapat beliau ini sejalan dengan Hadis Nabi saw.:

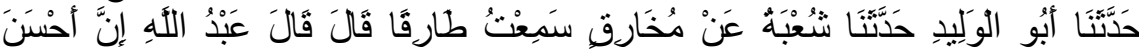

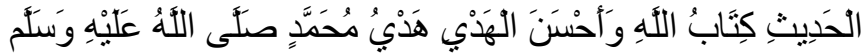


Ibn Jama'ah mensyaratkan mempelajari al-Quran terlebih dahulu karena dengan demikian pelajar akan dapat lebih mendalam hafalannya, bersungguh-sungguh dalam mendalami tafsir al-Quran, serta seluruh ilmu karena al-Quran memuat sumber, cabang, dan ilmu-ilmu penting lainnya. ${ }^{43}$ Sudah seyogyanya jika Ibn Jama'ah memprioritaskan al-Quran sebagai materi pertama yang harus dikaji oleh para pelajar, karena di dalam al-Quran terdapat ayatayat yang mampu menjadi motivator bagi pengembangan ilmu pengetahuan. Karena al-Quran pula maka lahirlah ilmu-ilmu lain, seperti Ulum al-Quran, Tafsir, Fiqh, dan semacamnya. ${ }^{44}$

b. Pelajar harus waspada terhadap perbedaan pendapat para ulama dalam suatu masalah. Pelajar yang berada dalam tahap awal, hendaknya jangan mempelajari pendapat-pendapat yang saling bertentangan dan jangan sampai terjebak pada masalah-masalah yang diperdebatkan ulama maupun manusia secara umum, karena hal ini dapat membingungkan akal. Pelajar yang masih pemula seharusnya memegangi satu kitab saja yang mencakup suatu masalah atau beberapa kitab yang masih berkaitan dengan masalah tersebut dan harus disetujui oleh gurunya. ${ }^{45}$

c. Pelajar harus memahami, mengkaji, dan menelaah secara mendalam terhadap setiap mata pelajaran sebelum menghafalkannya, karena jika tidak demikian dikhawatirkan akan menimbulkan penyimpangan dan pengkaburan makna yang dikehendaki. ${ }^{46}$

d. Pada tahapan selanjutnya pelajar hendaknya mempelajari Hadis Nabi Saw, yakni di antaranya dengan mempelajari sanad, rijal, hukum-hukum, faedah-faedah, bahasa serta sejarah Hadis. Di samping itu beliau juga menganjurkan untuk mempelajari ilmu dirayah Hadis, sifat-sifat dan tingkatan muhaddis. Ibn Jama'ah menganjurkan pelajar untuk mempelajari kitab-kitab Hadis yang dianggap / telah dinyatakan Sahih. Misalnya: Sahih bukhari,

${ }^{43}$ Ibn Jama'ah, Tazkirah al-Sami' wa al-Mutakallim, 112-113.

${ }^{44}$ Suwito, Pendidikan Yang Memberdayakan, 19-20.

${ }^{45}$ Ibn Jama'ah, Tazkirah al-Sami' wa al-Mutakallim, 116.

${ }^{46}$ Ibn Jama'ah, Tazkirah al-Sami' wa al-Mutakallim, 122. 
Shahih Muslim, al-Muwaththa', Sunan Abu Daud, al-Nasai dan kitab-kitab sahih lainnya. ${ }^{47}$

e. Pelajar harus melanjutkan mempelajari masalah lain yang lebih luas, untuk menunjukkan semangatnya yang tinggi dalam menuntut ilmu dan tidak merasa cukup dengan ilmu yang sedikit. ${ }^{48}$

f. Pelajar agar membiasakan diri untuk ber-halaqah dengan para guru dan juga dengan teman-temannya untuk mendalami pelajarannya serta agar memperoleh kebaikan, keberhasilan, dan keutamaankeutamaan.

g. Ketika mendatangi suatu majlis (forum belajar) pelajar hendaknya mengucapkan salam ketika datang, mengikutinya sampai selesai, memuliakan guru, menghormati teman-teman yang ada di sekitarnya, dan lain-lain. ${ }^{49}$

h. Pelajar hendaknya menghormati dn menghargai teman-teman yang ada dalam suatu majlis belajar. ${ }^{50}$

i. Adanya komunikasi antara pelajar dengan guru. Seorang pelajar hendaknya tidak malu dan enggan bertanya kepada guru terhadap masalah yang belum dipahaminya. Adapun dalam bertanya hendaknya pelajar mendapat izin dari guru. ${ }^{51}$

j. Bersungguh-sungguh dalam belajar, dan memulai belajarnya dengan doa yaitu dengan membaca ta'awudz, basmalah, shalawat, serta mendoakan guru dan pengarang kitab yang dipelajarinya.

k. Senang dalam mencapai keberhasilan. ${ }^{52}$

Dari uraian di atas, tampaknya Ibn Jama'ah sangat mendorong pelajar untuk menuntut ilmu secara sistematis dan agar pelajar beretika dan berakhlak mulia dalam belajar, walaupun pada sebagian pemikirannya terdapat pendapat-pendapat yang kurang relevan dan dapat menjadikan pelajar sebagai orang yang pasif dan mengalami kejumud-an dalam berpikir jika diterapkan dalam konsep pendidikan

\footnotetext{
${ }^{47}$ Ibn Jama'ah, Tazkirah al-Sami' wa al-Mutakallim, 126-131.

${ }^{48}$ Ibn Jama'ah, Tazkirah al-Sami' wa al-Mutakallim, 133.

${ }^{49}$ Ibn Jama'ah, Tazkirah al-Sami' wa al-Mutakallim, 146.

${ }^{50}$ Ibn Jama'ah, Tazkirah al-Sami' wa al-Mutakallim, 152.

${ }^{51}$ Ibn Jama'ah, Tazkirah al-Sami' wa al-Mutakallim, 156.

${ }^{52}$ Ibn Jama'ah, Tazkirah al-Sami' wa al-Mutakallim, 162. 
yang memberdayakan dan membebaskan terhadap proses berpikir para pelajar, sebagaimana yang sedang digalakkan saat ini.

\section{Kesimpulan}

Konsep pendidikan Ibn Jama'ah merupakan konsep pendidikan yang cenderung memposisikan pelajar sebagai objek dalam pendidikan, sehingga pelajar kurang mendapat kesempatan untuk 'diberdayakan'. Pelajar hanya dipandang sebagai manusia yang menerima dan menyimpan segala pengetahuan yang diperolehnya dengan tanpa diberi kesempatan untuk bersikap aktif, kreatif dan inovatif. Dalam hal ini, penulis dapat menggolongkan pemikiran Ibn Jama'ah mengenai pelajar ini sebagai pemikiran pendidikan yang bersifat normatif, karena pemikirannya hanya berdasar pada norma-norma yang cenderung teoritis dan dogmatis, yang orientasinya lebih pada tujuan keakhiratan dan kurang memperhatikan implementasinya secara riil. Oleh karena itu konsep ini kurang relevan jika diterapkan pada konsep pendidikan sekarang yang membutuhkan paradigma baru dengan memposisikan pelajar sebagai subjek dalam kegiatan belajar-mengajar.

Lebih lanjut tentang pemikirannya mengenai ketaatan kepada guru secara mutlak, akan berakibat pada terlahirnya orang-orang yang memiliki sifat inferior (minder). Bila dihadapkan pada konsep pendidikan modern yang menekankan nuansa kemerdekaan berpendapat dan pemberdayaan pelajar, maka akan terjadi kondisi yang kontraproduktif yang berakibat pelajar menjadi pasif.

Meski demikin, tidak semua pemikiran Ibn Jamaa'ah yang berkaitan dengan konsep pendidikan tidak sesuai dengan kondisi kekinian, karena sebagian konsep pendidikan yang ditawarkan masih relevan dan cocok jika diterapkan pada pelaksanaan pendidikan saat ini (misalnya, pemikirannya berupa pelajar harus selalu menghiasi dirinya dengan akhlak mulia ketika menuntut ilmu). Oleh karena etika merupakan media self-control (pengawasan melekat) terhadap diri pelajar yang dapat menghindarkannya dari hal-hal negatif, dimana hal ini berguna untuk mendukung kesuksesannya dalam belajar. 
Ahmad Yusam Thobroni

\section{DAFTAR PUSTAKA}

Ahmad Ibn Hanbal, Musnad Ahmad bin Hanbal, no. hadis 21152, CD ROM Mausū'ah al-Hadis al-Syarīf (Kuwait: Sakhr al-'Alamiah Software, 1996)

Abd al-Jawad Khalaf, Al-Qādli Badruddin Ibn Jamā'ah Hayātuhu Wa Atsaruhu, (Pakistan: Jami'ah al-Dirasah al-Islamiyyah,1988).

Abuddin Nata, Pemikiran Para Tokoh Pendidikan Islam, (Jakarta:Raja Grafindo Persada, 2000)

Abd. al-Amir Syamsuddin, al-Mazhab al-Tarbawiy 'inda Ibn Jamā'ah (tt.: Dar Iqra', tth.)

Ali Ashraf, Horizon Baru Pendidikan Islam (Jakarta: Pustaka Firdaus, 1993)

Badri Yatim, Sejarah Peradaban Islam (Jakarta: Raja Grafindo Persada, 1995)

Departemen Agama RI, Al-Quran danTerjemahnya (Jakarta:PT.Bumi Restu, 1976).

Hasan Ibrahim Abd 'Al, Al-Fikr al-Tarbawiy 'inda Badruddin Ibn Jamā'ah dalam Min A'lām li al-Tarbiyah al-Islamiyyah, jilid III (tt.: Maktabah al-Tarbiyah al-'Arabi li dauli al-Khalij, tth.)

Ibn Jama'ah Al-Kinaniy, Tazkirah al-Sāmi’ wa al-Mutakallim fi Adab alĀlim wa al-Muta'allim (Beirut:Dar al-Kutub al-Ilmiyah,tth.)

Mulyono Abdurrahman, Pendidikan Bagi Anak Berkesulitan Belajar (Jakarta: PT. Rineka Cipta,1999)

M. Arifin, Hubungan Timbal Balik Pendidikan Agama; di Lingkungan Sekolah dan Keluarga (Jakarta: Bulan Bintang, 1976)

Paulo Freire, Pedagogy Of The Oppressed, diterjemahkan oleh Tim Redaksi LP3ES dengan judul Pendidikan Kaum Tertindas (Jakarta: LP3ES, 2000)

Suwito, Pendidikan Yang Memberdayakan, dalam pidato pengukuhan Beliau sebagai guru besar sejarah pemikiran dan pendidikan Islam, UIN Syarif Hidayatullah Jakarta, 2002. 